\title{
$I \mathbb{O} S \mathbb{E} S$
}

International Journal of Social and Educational Sciences - Uluslararast Sosyal ve Eğitim Bilimleri Dergisi Volume 3, Issue 5, June 2016 \& Cilt 3, Sayl 5, Haziran 2016

ISSN: $2148-8673$

\section{SANAT DEĞERININ ÇEVIRIYYE ETKISI}

\author{
THE EFFECT OF ARTISTIC VALUE ON THE TRANSLATION
}

\author{
Özber CAN*
}

\section{$\ddot{O} \mathbf{z}$}

Bu makale Venedik'te Ölüm başlığıyla Almanca'dan Türkçe'ye çevrilen romanın dil-üslûp çerçevesinde sözdizimi ve anlam sapmalarını inceler. Hedef dilde akıcı, etkin metin kurma uğraşısı okurun algısını yanılttığ 1 için karşılaştırma yöntemiyle ticari ve akademik çevirileri bir araya getirir. Özgün metnin edebi yöntemlerle aktarılma zorunluluğuna rağmen çeviri metinde okuma hazzı ve ahengin zayıflamasını, sanat kaybını örnekler. Çevirmenin sınırlılıklarını, sanat değerinin çeviriye etkisini, okur algısının seviyesini değiştirmesini açığa çıkarır.

Anahtar Sözcükler: Venedik’te Ölüm, Sanat Değeri, Edebi Çeviri, Dilin Materyal Unsurları, Anlam ve Sözdizimi Sapmaları

\begin{abstract}
Absract
This article examines the syntactic and meaning deflections within the language and manner aspects of the novel that's been translated from German to Turkish with the title death in Venedig. Because the stuggle in producing a text with a fluent, effective manner in the target language deludes the readers perception, it bring together the commercial and academic translations with the comparison manner. Desptite the inevitibality to narrate the original text in a literary manner, it models the diminution in the pleasure of reading and coherence, and the loss of the art in the translated text. It reaveals the translators limitations, the effect of the artistic value on the translation and the change of the readers perceptic level.
\end{abstract}

Keywords: Death in Venedig, artistic value, literature translation, material elements of language, meaning and syntax deviations

*(Yrd. Doç. Dr.); Necmeddin Erbakan Universitesi, Ahmet Keleşoğlu Eğitim Fakültesi, ozbercan@ hotmail.com 


\section{GÍRIŞ}

Sözlü ya da yazılı eserlerin yapı ve anlamca mutlak sanat değerleri vardır. Yapı kelimeler, cümleler, paragraflar ve bütün metinle, anlam ise sanat ve materyal unsurlarıyla işlev kazanır. Dil, bu karmaşık gibi görünen öğeleriyle anlaşılmazı anlaşılır kılar; eser, edebiyata açılan kapılarıyla hayata da açılır. Kurmaca kelime seçimi, tonlama ve anlam, uzun ya da kısa sözdizimleri, duygu değeri, metinlerin açık-kapalılığıyla anlaşılmayı bekler. Kaldı ki metinlerin, "abartma, anafor, bilinç akımı, çağrışım, diafor, eksilti, gerilim, gönderme, imge, imaj, kara mizah, kolaj, metonomi, mit, motif, örtmece, parabol, retorik, simge, tersinleme, yabancılaştırma"1 gibi sanat unsurlarıyla anlaşılması tam bir muamma, çevirileriyse sırların çözümü kadar zordur. Çünkü bir eserin sanat değeri, işlediği gerçeklikle inandırıcılığı sağladığı ölçüde güçlenir; güçlendikçe de diğer bir kültüre aktarımı zorlaşır. Öyle de olsa değişimin yeterlik düzeyini zorladığı bugün, "dizgesel dilbilim (Systemlinguistik)"'2 sayesinde metinbilim düzlemi, yabancı dil bilmeyen okura çeviriyle yakınlaşmaktadır. Ancak yapı, anlam, gerçeklik, duygu ve estetik değerlerin yanı sıra, "kültürbilimsel bakış açısını öne çıkaran yaklaşımlar"3 aktarımda bir dizi engeldir. Oysa edebiyat ve dilbilim arasında bir disiplin oluşuyla çeviribilim, sadece iletişimi değil, eşdeğer olanı kurmayı bekler. Bu süreçte bir dizi bilgi ve kuraldan söz edilse de kabul gören genel-geçer bir çeviri kuramından söz edilmez. Ayrıca bilimsel dizge eksikliği ve bağdaşmazlığın, hem genel bir çeviri kuramının doğmasını engellediği hem de, "kuram denemelerinin paradigma anlamında uyuşmazlığ1 sonucunu doğurduğu" düş̧ünülmektedir. Yine de yaklaşım uyuşmazlıklarının, "çeviribilim için kaçınılmaz olan disiplinlerarasılığın belirsizliğinden"5 kaynaklandığı, çeviribiliminse, "disiplinlerarası bir bilim"6 olmasıyla sosyokültürel etkileşimlerden beslendiği yadsınamaz. İpuçları vermesiyle kültür, kuram ve metnin çeviriye etkisi çeviribilimin özel konumuna kısmen gölge düşürdügü için diğer bilimlerin bu alana, "keyfi müdahalesi"7 çeviriyi derinlikli düşünmeyi gerektirmektedir. Ki bu durumda çevirmen sanatçının yakasına değil, eserinin yoruma ve yeniden yazmaya kapalı kelimelerine, satırlarına yapışabilir. Yahut da anlatılanları birleştiren her bir işaretin, kelimenin veya söz öbeğinin anlamına odaklandığ 1 sürece yakasını okurun ellerinden kurtarabilir. Buradaki kalfalığı sanatçıya, çağa ve çevresinde yaşananlara bakış ustalığına dönüştükçe, kastı anlamlandırma kolaylaşacaktır. Thomas Mann işte bu bakışı bekleyen ustalardan biridir.

\section{A. THOMAS MANN - SANAT ANLAYIŞI}

20. yüzyılın önemli Alman yazarlarından Thomas Mann, 1875'te Lübeck’te doğar. Varlıklı bir ailenin çocuğudur. Okula istemeyerek gider. Dolayısıyla öğrencilik hayatı parlak geçmez.

\footnotetext{
${ }^{1}$ Gürsel Aytaç, Genel Edebiyat Bilimi. İstanbul: Say Yayınları, 1. Baskı, 2003, s. 323-378.

2 Mario Wandruszka, Die Mehrsprachigkeit des Menschen, München: Piper, 1979, s. 133 (Bkz. Werner Koller, Einführung in die Übersetzungswissenschaft, 4. Auflage, Quelle\&Meyer, Heidelber, 1992)

${ }^{3}$ N. Lew Zybatow, Sprache-Kultur-Translationoderwieso hat Translationetwas mit Sprachezu tun?, In: Translation zwischen Theorie und Praxis. Inssbrucker Ringvorlesungen zur Translationswissenschaft I. Forum Translationswissenschaft Bd. I. Lang Verlag: Frankfurt, 2002, s. 61-82.

${ }^{4}$ Zybatow, 2002, a.g.m. s. 81.

${ }^{5}$ Wolfram Wills, Interdiziplinerität: ein neues übersetzungswissenschaftliches Paradigma?, In: Paradigmenwechsel in der Translation: Festschrift für Albrect Neubert zu 70. Geburtstag/Hrsg. Von Peter A. Schmitt, Tübingen: Staufenburg, 2000, s. 265-279.

${ }^{6}$ Mary Snell-Hornby, Übersetzungswissenschaft-Eine Neuorientierung, UTB-Wissenschaft, Francke Verlag, TübingenBasel, 2. Auflage, 1994, s. 12; (Bkz. Albrecht Neubert, Translationstudies and applied Linguistics, In AILA Review I, 1984)

${ }^{7}$ İsmal İşcen, Çevrim Kuramı, Seçkin Yayınevi, Ankara, 2002, s. 72.
} 
Ancak okumayı Goethe ve Schiller'in eserleriyle sevdiren edebiyat öğretmenine hep mihnet duymuştur. 16 babasını kaybedince baba mesleği ticaret geride kalır. Ailenin Münih'e taşınmasıyla birlikte sanata olan ilgisi artar. 19 yaşında bir sigorta şirketinde çalışmaya başlaması, edebiyat serüvenini de başlatır. Ne var ki öğrencilik yıllarında kaleme aldığ 1 şiirler karalama da olsa ailenin itibarını sarsar. Özel derslerle büyüyen, büyük bir firmanın varisi genç Thomas aşk şiirleri yazmamalıdır. Üzerindeki baskı o dönem sanata olan ilgisini kırsa da onun kalktığını hissetmesiyle birlikte edebiyata dört elle sarılır.

Thomas Mann'ın gelişiminde birçok besteci, orkestra şefi ve akademisyenle kurduğu dostluğun, özellikle de müziğin önemli rolü vardır. Tiyatro denemelerinden sonra Buddenbroks (Buddenbrooklar), Zauberberg (Büyülü Dă̆) ve Doktor Faustus (Doktor Faust) gibi romanları ve Der Tod in Venedig (Venedik'te Ölüm) uzun hikayesiyle dünya edebiyatına girer. 1910'da Münih’te prömiyerine katıldığı Mahler Senfonisi'yle, "Mahler izlerini bu romanın merkezi karakterine, Gustav von Aschenbach'a aktardı̆̆ı"8 hatta Venedik'te Ölüm'ün, "Mahler'in 1911 yılında ölümünün etkisiyle yazılmış" olduğu ileri sürülür. Buddenbrooklar ile burjuva ailenin, Venedik'te Ölüm'le de sanatçı ahlâkının çöküşünü işleyen Mann, Nazi rejimine karşı çalışmasının bedelini 1936'da Alman vatandaşlığından çıkarılarak, önce İsviçre'ye ve zaman sonra da ABD'ye göçerek öder. Irkçı politikaların sonlanmasıyla Goethe'yi anma toplantılarına katılmak üzere 1949'da ülkeye döndügünde, edebiyatçılar tarafından soğuk karşılanır. Oysa o Avrupa'yı peşine düşüren Goethe'nin izinden gitmekte; izlenimleriyle Batılı aydınlardan farklı bir yolda yürümektedir.

Sanatçılığı açısından Mann, "eserlerinin eleştirel-metafizik içeriğini Nietzsche ve Schopenhauer'e, biçim ve kurgusunu Tolstoy'a borçludur."10 Ayrıca kendini ifade etme cesareti, cinselliğe yaklaşımı ve içgüdüleri Freud'un, kendini eğitme, onaylama ve güçlendirme çabası ise Goethe'nin eseridir. Çağdaş Avrupa eleştirel gerçekliğinin ve 20. yüzyıl Alman romanın bu önemli temsilcisi, içine hayat hikayesini kattığı eserlerinde öznelliğe sıkışıp kalmaz. Gürsel Aytaç'ın ifadesiyle o, "yaşayan, yaşamayı bilen, oyundan, şölenden hoşlanan, büyüklerin, zenginlerin sofrasında bulunmaktan çekinmeyen, tek eksiği namus (Anständigkeit) olan biridir."11 Keyfince gözlemler ama karar vericilerle bir araya gelmez. Politik biri olmasa da apolitik de değildir. Prusya Sanatlar Akademisi'nde Liebermann'ın Nasyonalizm kokan Devlet ve sanat, Alman insaninin kafasında ulusal hayatın birbirine bağlı organlarıdır.(1926) sözüne karşı çıkarak, Her sanatçı kendi kendisinin akademisidir. tezinin kovalayıcısı olmuş; toplumla ilişkisini koşulların hep sözcüsü oluşuna bağlamıştır. Edebiyatın ırkçılığa yenik düştüğü yıllarda düşüncesini söylemekten çekinmeyen yanı ve I. Dünya Savaşı sırasındaki milliyetçi tutumu, sanata ilişkin görüşlerinde etkindir. Sanatla savaş özdeşliği ve siyasetle edebiyat iliş̧isinin, bireyin kendisini bulmasına imkân verdiğini düşünür. Kendi ifadeleriyle, "Bunun sebebi yalnızca [...] dünyaya yaranmak değildi, tam tersine burada [sanatta] insani olanda anlaşma ve kendini bulma imkânının, tek kelimeyle barış imkânının ima edilebilir olduğunu görmemdi."12 Ailesinin beklentilerine rağmen sanatı seçmesi, "yazarlık ve toplum konusundaki görüşlerinde, kurmaca eserlerinin figürlerinde" 13 belirginleşir.

\footnotetext{
8 Erdem Çöloğlu, Venedik’te Ölüm, Mann-Britten-Visconti Üzerinden Karşılaştırmalı Bir Analiz, (http://www.msgsumuzikoloji.com)

${ }^{9}$ Michael Oliver, E. Benjamin Britten, Phaidon, Londra-İngiltere, 1996, s. 204.

${ }^{10}$ Klaus Schröter, Thomas Mann, (Çev. Özden Saatçi-Karadana), Kavram Yayınları, İstanbul, 1999, s. 67.

${ }^{11}$ Gürsel Aytaç, Thomas Mann'ın Edebiyat Dünyası, Phoenix Yayınları, Ankara, 2010, s. 121.

${ }^{12}$ Hans Wysling, Dichter über ihre Dichtungen, Buch 14/1, Heimeran/S. Fischer, 1975, s. 139.

${ }^{13}$ Gürsel, 2010, a.g.e. s. 125.
} 
1929'da Nobel ödülüne lâyık görülen Venedik'te Ölüm ve ana karakteri yazar Aschenbach bunun en belirgin örneğidir.

\section{A. a) Venedik'te Ölüm}

Eser, 1912 yılında kaleme alınır ve 1913'de yayımlanır. Bir yaklaşıma göre, "sanatçının çocukluk yıllarından başlayarak büyümesini, yetişmesini, sanatçı olmaya karar verişini" 14 işler. Bir diğer yaklaşıma göre de, "eleştirici ve ironik mesafe içinde dile getirilmiş ahlâksal bir tükenişin hikâyesi" "15 sayılır. Uzun hikaye özelliğiyle Künstlerroman (Sanatçı Romanı), kendini yetiştirme ve bilinçlenme tematiğiyle de yetişme Bildungsroman (Çă̆ Romanı) olarak okunur. Ellisine gelmiş yazarın yeniden doğuş ve gerilimlerinden kurtulma arzusu, bir gemi yolculuğuyla başlar. Ünlü yazar Aschenbach'ın Venedik'te yerleştiği otelde Tadzio'nun olağanüstü güzelliğine tutulması, eserin dönüm noktasıdır. Onun ideal güzelliğe duyduğu tutku, onu izleyerek günlerini geçirmesine, içgüdüsel düşüncelere sürükleyecektir. İlk okunduğunda garip bir huzursuzluk, tatsız bir rahatsızlık duyumsatan eser, "pedofili günahına"16 bulaşmışlık hissi uyandırır. Kelimeler yer yer okuru suçluluğa sürükleyecek kadar sessizleşmiştir. Yazar, "insanlığın bu acınası çıkmazını derin bir psikolojik analiz ve lirizmle" 17 betimlerken ahlâk, ölüm ve aşk üçgeninden çıkamaz. Sanat birini daha ağına düşürmüş, güzele olan teslimiyetle ahlâki değerleri çökertmiştir. Romantizmin doruğuna ulaşan konu, uzun bir roman okuyuşuyla ilerlerken, "sanat, sanatçı, hayat ve hazzı sorguladığı" 18 noktalarda okura sıklıkla Ne oluyor? dedirtir. Aschenbach, gizlendiği yerde önünde sere serpe sergilenen vücudu izlerken duyduğu derin hayranlığı ve gözledikleriyle oluşan yargısını bir diğer yerde kırıverir. Burada yazar Tadzio ile Platon'un güzel idea'sını cisimleştirmiş, ütopik fanteziyle davranış kültürünü eleştiriye açmıştır. Mann'1 harekete geçiren, sanatın anlamını psikolojinin desteğiyle açıklaması, sanatın ve sanatçının sorumluluk alanında olumsuzu merkeze almasıdır. Bu tavrı ve antik etkiye yakın duruşu, "mantıkla duyguları amansız bir savaşa soktuğu" 19 ile yorumlanacak; kendisine, "mükemmelliğiyle insanı 'yazmaktan korkar' hale getiren" ${ }^{20}$ sanatçı dedirtecekti. Ona sıra gelmeden hastalık derecesinde büyüyen tutku ve içten gelen ses gençliğini aratmıştır. Kırlaşmış saçları, kırışmış yüzü ve elleriyle orta yaşın üstünde Aschenbach'ı geride kalan y1llarına öykünerek gençleştirmiş; sükûn ile ona ölümü bekletmiştir. Aschenbach'a Tadzio ile gösterilen güzel/güzellik, din etkisiyle oluşan bir motif olarak da algılanabilir.** Burjuvazinin yozlaşmasını önemseyen Mann'ın tıpkı Goethe gibi inançlı bir Hıristiyan olmaması, hatta onun İslâm'a duyduğu hayranlığa, doğallığa özenmesi, buyaklaşımı doğrulayabilir. Belki de göz, asil doğallığı ve arılığı gördükçe, ayak aklın zoruna düşmüştür. Bu bakımdan kahramana sanatçı vermesi, onu hem yüceltmiş, hem de eleştirilere maruz bırakmıştır. Onun edebi yükselişi, sorunu

\footnotetext{
${ }^{14}$ Nazan Aksoy, Kurgulanmış Benlikler, İstanbul: İletişim Yayınları, 2009, s. 22

${ }^{15}$ Hüseyin Arak, Thomas Mann'ın Venedik’te Ölüm Başlıklı Eserinde Sanatçı İmajı, s. 3 (http//:egitim.erciyet.edu.tr)

${ }^{16}$ Yücel Nural, Venedik’te Ölüm ve Rousseau, 30.01.2013, (www.dipnotkitap.net)

${ }^{17}$ Yücel, 30.01.2013. a.g.m.

${ }^{18} \mathrm{http}: / / \mathrm{www} \cdot$ benolmeden.com

${ }^{19}$ Murat Özer, Mantığın Bir Anlık Çöküşü, Radikal Kitap, 19.08.2011.

** Goethe'nin Divan'a aldığı Züleyha, ahlâk ve yüz güzelliğiyle yaşlı Hatem'in varlık nedenidir. Faust'un, Şeytan'ın kandırmasıyla son günlerine kadar güzelliğin peşinde coğrafyalar dolaşması onun hayata bağlılık nedenidir. İslâm inancına göre Allah'ın yeryüzündeki halifesi insana verdiği güzelliğin özde Gerçek'in bir yansıması ve Ademoğlu'nu peşine düşürmesi gibi. Kuyudan çıkarılarak Mısır kralına satılan Yusuf'un bilgeliği dışında ahlâki ve yüz güzelliğiyle Mısır Melike'sini büyülemesi, karşılıksız tutkunun zindana sürüklemesi gibi. Türk Halk Edebiyatına yansıyan ân'ın silinmesine mâni olacak kadar güçlü ama kavuşunca ölüverecek kadar narin mum-pervane ilişkisi, esin olarak mağlubiyet haliyle Batı'ya geçmiştir.

${ }^{20}$ Murat, 19.08.2011.a.g.m.
} 
ve yitişi, eseriyle mazbuttur. Bunlara yabancı olan okur, kültürel birikimi ve beslendikleriyle yetinmektedir. Ki eğer beslendiği bir çeviri eserse, anlatanın anlattıklarını irdeleyip duracaktır. Sanatın gücü, aktarımda retorik ustalığı gerektirdiği için perdelenen söylemi ve söz uçlarını verilen bilgiler ışığında iyi irdelemek, çeviri aralığında onları edebi anlamlarıyla düşünmek durumundadır.

\section{B. EDEBİ ÇEVİRI}

Çeviri, gelişme süreçleri sonrasında bugün alana özgü bir uygulama düzeyine ulaşmış; kavram, metodoloji ve kültürel özellikler çerçevesinde, "iki kültürün karşılaştığı yerde"21 çoğu zaman ihtiyaç haline gelmiştir. Dünya giderek küreselleşirken hem sözel hem de yazılı aktarımlarda sözün anlaşılması için kaynak metnin yeni bir metne dönüşmesi, bu ihtiyacı gerekli kılmaktadır. Ancak söylenilen şey diğer kültürde anlamlanırken ekleme, eksiltme, dolaylama... yollarıyla yapı ve anlam kayıplarına uğramakta; edebi eserin dil unsurları, sanat ve duygu değerleriyle aktarımı, karşı kültürde aynı etkiyi uyandırma özeni, güçlükleri katmanlaştırmaktadır. Öte yandan okuma esnasında irdelemelere takılan, okuru ara sokaklara götüren çeviri, "yaprakların hışırtısını kesmeden kökleri eşelemek zorunda kalan" 22 çevirmenle daha da zorlaşmaktadır. Yine de olanca zorluğa rağmen anlam, söylem ve üslûbun diğer kültür dizgesine olduğu gibi aktarılması, ustasını beklercesine ortadadır. Mann, söyleminin yanlış anlaşılabileceği kuşkusuyla çeviriye kuşkulu bakar. Sanatçı saygınlığını koruyan, "bir yabancı dilin el verdiği ölçüde tıpatıp aktarılması"23 değil midir? Çünkü edebi çeviri yazara dışa açılma imkânı verse de kıstas, özgün metnin dili ve sanat özellikleriyle eşdeğer (Äquivalenz) aktarımıdır. Burada uyulması gerekli bir dizi zorunluluk sapmalarla boğulurken, sanatçının çağa, sosyolojik ve psikolojik gelişmelere bakışı yakından tanındıkça söylemine yaklaşılabilmektedir. Kültürler birbirini etkilese de ortak dil arayışı çeviriyi canlı tutmaktadır. Venedik'te Ölüm gibi Almanca'dan Türkçe'ye çevrilen pek çok eser, değerlerin yok oluşunu sorgulamasıyla okunmakta, anlaşılmayı beklemektedir.

\section{B. a ) Dil ve Üslûp}

Sanat, gerçeklik ve kurguyu birleştirir; okurun duygu ve düşüncelerine açıklık, zenginlik getirir. Onları taşıyan dil, insana özgü iletişim aracı olmasıyla, üslûpsa anlatım becerisiyle işlevseldir. İkisi de sanatçı eliyle özelleşir, estetik değer kazanır. Kurmaca eserlerde dil en az iki dünyayı tanıtırken, "anlatımın estetik zarfı ve dilin bireysel ifadesi"² üslûp özgünleşir. Almanca'nın mantık ağırlıklı, karmaşık yapılı öğeleri, sanatın gücüyle yumuşar; tasvirlerle yoğunlaşır. Türkçe ise otantik kültürün zenginliği ve sıcaklığıyla bu tasvirleri anlamlandırmaya uzak değildir. Adı geçen öykünün uzun cümleleri ve ayrıntılı tasvirlerine rağmen anlatı bütünlügünün getirdiği boşluksuz okuma, kelimelerin büyüleyiciliği ve şiirsel dokusu çevirmeni kolayca teslim aldığı görülmektedir. Onların usulca ilerleyen duygularını bir anda tahrik eder; hatta hayat ve ölüm ikilemini aynı resme sığdırır. Hedef dilden ana dile çevrilen Venedik'te Ölüm, bu izleğiyle çevirmenlere eşit uzaklıktadır. İnsanın başını eğip güzelliğe teslim olması, sanatçının kendine yenik düşmesi, "iç savaşın dışavurumu" 25 şeklinde okunurken, çok türde cümle yapısı ve kelime anlaşılırlığa yol vermektedir. Vurgu, benzer kelimelere bırakılarak, olayın farklı boyutlarının gösterilmesi, yazarın evinden çıkmasıyla birlikte başlar.

\footnotetext{
${ }^{21}$ F. Sakine Eruz, Çeviribilim-Çeviriden Çeviribilime, Multilingual, İstanbul, 2003, s. 41.

${ }^{22}$ Edmond Cary, Çeviri Nasıl Yapılmalı?, (Çev. Mete Çamdereli), İnsan Yayınları, İstanbul, 1996, s. 48.

${ }^{23}$ Hans, 1975, a.g.e. s. 521.

${ }^{24}$ Mehmet Tekin, Roman Sanatı I (Romanın Unsurları), Ötüken Yayınları, İstanbul, 2001, s. 166.

${ }^{25}$ Murat, 19.08.2011, a.g.m.
} 
Örnek 1. "Gustav Aschenbach oder von Aschenbach, wie seit seinem fünfzigsten Geburtstag amtlich sein Name lautete, hatte an einem Frühlingsnachmittag des Jahres 19.., das unserem Kontinent monatelang eine so gefahrdrohende Miene zeigte, von seiner Wohnung in der PrinzRegentenstrasse zu München aus allein einen weiteren Spaziergang unternommen."26

"Gustav Aschenbach ya da ellinci doğum gününden beri resmen taşıdığı asalet unvanıyla Gustav von Aschenbach; kitamızda aylarca tehlike havası estiren 19... yılının ilkbaharında bir ikindiüstü, Münih'te Prinzregenten Caddesi'ndeki evinden, bir başına uzunca bir gezintiye ç1kmışt1." 27

“Gustav Aschenbach ya da ellinci doğum gününden beri resmi olarak da söylendiği gibi Gustav von Aschenbach, bizim kıtada aylarca tehdit havaları estiren $19 \ldots$ yılının bir ilkbahar günü öğleden sonra, Münih'te Prinz-Regenten Caddesi'nde bulunan evinden bir başına uzunca bir gezintiye çıkmışt..’(Yasemin Acar)

"Gustav Aschenbach, ya da doğumunun 50. yılından beri resmi olarak bilinen asil ünvanıyla, von Aschenbach; kıtamızda aylarca bir tehlike havası estiren $19 \ldots$ yılının ilkbaharında, öğleden sonra Münih'te Prinz-Regenten Caddesi'ndeki evinden, yalnız başına uzunca bir gezintiye çıkmıştı."(Ferhat Dönmez)

"Gustav Aschenbach ya da ellinci doğum gününden beri resmi adı olan Gustav von Aschenbach, kıtamızda aylarca tehlikeli bir rüzgar estiren $19 \ldots$ yılının bir ilkbahar ikindisinde Münih'te PrinzRegenten Caddesi'ndeki evinden tek başına uzun bir gezintiye çıkmıştı." (Zeynep Yıldız)

"Gustav Aschenbach ya da ellinci doğum gününden beri resmen taşıdığı unvanıyla Gustav von Aschenbach, kıtamızda aylarca tehlike havası estiren 19. yüzyılın ilkbaharında bir öğleden sonra Münih'te Prinz-Regenten Sokağında bulunan evinden tek başına bir gezintiye çıkmıştı."(Sümeyra Tokmak)

Çevirmen Behçet Necatigil ve yüksek lisans öğrencilerinin esere daha ilk cümlede farklı yaklaştığı görülüyor. Necatigil, hem cümleyi bir (;) işaretiyle ikiye bölüyor, hem de von ile kastedilen soyluluk nişanını, eserin kaleme alındığı zamanın diliyle aktarıyor. Bu yetkinliğe rağmen özne gurubunu ilgi ve eylem cümlesinden ayrı görmesi, özgün cümleyi benzer iki cümle ile yapılandırması, okuru ve diğer çevirmeni etkiliyor. Frühlingsnachmittag, gefahrdrohende Miene bileşik kelimeleri ve Name lautete gibi söz öbekleri, metnin söylemini güçlendirdikleri halde farklı bir algı uyandırıyormuşçasına Türkçe'ye benzer, dolaylı, eklemeli ve özgürce aktarılıyor. Öyle ki bir öğrenci cümlesine gibi eklemesini yapıyor, bir diğeri ikindiüstü zaman zarfını eksiltiyor; bir diğeriyse tehlike'yi beklenen sıfat anlamıyla çeviriyor. Metodolojik bir uygulama sayılmasa da yap1 öğeleriyle söylediklerinden daha fazla anlam ifade eden, "sanat formlarıla bezenmiş metinler" 28 estetik etki uyandırma amacının yanı sıra bir gerçeği de ifade ederler. Böylesi metinlerin kelimeleri öyle bir yük altındadır ki dil, durum, zaman ve mekânı betimlerken, aktif/pasif yapının, kişileştirme ayrıcalığının kaçırılmasına izin vermezler. Venedik'te Ölüm de çekingenlik, korkaklık ve kınanma kaygısını aşan cümleleri, mitolojik motifleriyle belirgindir. Yazarın, Apollon'un karakteristik özelliklerini taşıyan Aschenbach'ın aşağılanmasına göz yummaması ama bir yabancı tarafından baştan çıkarılmasına, Dionysos'un hâkimiyeti altına girmesine izin vermesi bundandır. Aschenbach-Tadzio fantezisinin amansız takip motifiyle eserin sonuna kadar sönmemesi de aynı gerekçeye dayanır. Aschenbach düşünce ve bedenen çürürken, Tadzio klasik güzelliğin ve iffetin simgesi olarak kalmaktadır. Okurun elini sıkıca kavrayan aydın-tutku ikilemi, doğa tasvirleriyle

\footnotetext{
${ }^{26}$ Thomas Mann, Der Tod in Venedig, Fischer Taschenbuch, 2007, s. 9.

${ }^{27}$ Behçet Necatigil, Venedik'te Ölüm, Can Yayınları, 4. Basım, 2009, s. 11.

${ }^{28}$ Katerina Reiss, Möglichkeiten und Grenzen der Übersetzungskritik, HueberVerlag, München, 1971, 84.
} 
bağlanırken, dil ve üslûp, gözlem ve ironiyle çeşitlenmektedir. Durağan akış, sade ve yalın dil, zengin tasvirlerle güçlenmiş; sıfat yoğunluklu cümleler zaman ve doğa ile bağ kurmuştur.

Örnek 2."Es war Anfang Mai und nach nasskalten Wochen, ein falscher Hochsommer eingefallen." ${ }^{29}$

"Mayıs başlarıydı; yağışlı, soğuk geçen haftalardan sonra birdenbire aldatıcı bir yaz bastırmışt1."

"Mayıs başlarıydı ve rutubetli, soğuk haftalardan sonra aldatıcı bir yaz gelmişti."(Yasemin Acar)

"Mayıs'ın başıydı, ıslak ve soğuk haftalardan sonra, yolunu şaşırmış bir yaz sıcağı gelmişti."(Ferhat Dönmez)

"Mayıs başıydı, soğuk ve yağışlı geçen haftalardan sonra yalancı bir yaz bastırmıştı."(Zeynep Y1ldiz)

"Mayıs başlarıydı, soğuk ve yağışlı haftalardan sonra, ansızın aldatıcı bir yaz bastırmıştı."(Derya Kara)

Es war Anfang Mai cümlesi Necatigil ve yüksek lisans öğrencileri tarafından çoğul-tekil zaman algısıyla çevrilmiş olsa da anlam bakımından çelişmemektedir. Ancak, Necatigil'in bu cümleyi de (;) noktalama işaretiyle bölmesi, çevirisine birdenbire eklemesini yapması dikkat çekicidir. Zaman ve havayı betimleyen falscher Hochsommer tamlaması ise, falsch sıfatının ilk anlamı dışında aldatıcı-yalancı anlamlarıyla, yolunu şaşırmış bir yaz sıcă̆ çevirisinden daha doğru bir anlam vermektedir. Nach nasskalten Wochen zarf tümleci ise soğuk ve yağışlı anlamlarıyla genişlerken, Acar'ın rutubetli, Yıldız'ın ve Dönmez'in tslak kelimeleriyle anlam bulan cümle, alg1 yönüyle farklılaşmaktadır. Özü fazlaca etkilemeyen bu doğallık, okuru yazara ve söylemine yine de birkaç çekinceyle götürecektir. Ancak Almanca cümledeki kelimelerin sıralanış ve anlamlarına sadık kalınarak yapılacak bir çevirinin de anlamı ve yapısı bozuk cümleler doğuracağı da açıktır. Yıldız'ın uyarlama ile yaptığı çeviride falsch sıfatını lügnerisch anlamıyla cümleye taşıması anlamlıdır. Türk kültüründe mevsimlerin vaktinden önce gelmesi durumunda yalancı sıfatıyla ifade edilmesi, gerekçeyi açıklamaktadır.

Üslûp, yazarın kendi yaşantılarından esinlendiğini kısmen gizlese de gözlem, düşünce akışı ve dinginlik arayışı neredeyse her karede hissedilir. $\mathrm{Bu}$ 1lımlı tarzın Goethe ekolünden geldiği, Mann'ın, "Goethe'ye hem insani anlamda hem de sanatçı noktasında yakınlığı" 31 anlaşılır.

Örnek 3. "So hatte er bald nach dem Tee das Freie gesucht, in der Hoffnung, dass Luft und Bewegung ihn wiederherstellen und ihm zu einem erspriesslichen Abend verhelfen würde." ${ }^{32}$

“.....o kadar gerekli ve hafifletici olan uykuyu da bulamayınca, çayını içtikten az sonra, havanın ve hareketin sinirlerini yatıştırıp kendisini verimli bir geceye kavuşturacağı umuduyla açık havayı tercih etmişti." 33

\footnotetext{
${ }^{29}$ Thomas, 2007, a.g.e. s. 9.

${ }^{30}$ Behçet, 2009, a.g.e. s. 11 .

${ }^{31}$ Gürsel, 2010, a.g.e. s. 51.

32 Thomas, 2007, a.g.e. s. 10.

${ }^{33}$ Behçet, 2009, a.g.e. s. 11.
} 
"Bundan dolayı, çayı içtikten sonra hava ve bedensel hareketin, sinirlerini yatıştırıp kendisini verimli bir geceye kavuşturacağı umuduyla açık havayı tercih etmişti.”(Ayșe Yılmaz)

"Çayını içtikten biraz sonra havanın ve dolaşmanın kendisini yatıştırıp verimli bir akşama kavuşturacağı umuduyla açık havayı istemişti.”(Derya Kara)

"Çayını içtikten hemen sonra, havanın o anki durumu, gezinti yapmanın sinirlerini yatıştıracağı ve kendisi için daha yararlı bir gece olacağı düşüncesiyle açık havayı tercih etmişti.”(Hatice Türk)

"Böylelikle kurtuluşu, kendisine tekrar kabiliyet ve enerji sağlayacak ve verimli bir akşam temin edecek umuduyla çayda aradı.”(Selman C. Yıldırım)

Necatigil'in, bir önceki cümleye eklenti olarak yaptığı bu çeviri cümleye bir öğrenciyle birlikte özgün cümlede olmayan neden bağlacı eklemesi, diğer öğrencilerle de sinirlerini yatıştırıp ifadesinde birleşmesi, ticari çeviriye uygun bir arayış sayılır. Wiederherstellen fiili yeniden harekete geçirme, ruhen yatıştırma, iyi gelme anlamlarıyla alınabilir; Luft ismiyle açık hava, verhelfen würde yapısıyla da henüz gerçek olmayan durum buluşmayı sağlayabilirdi. Türk ve Yıldırım bu cümlenin çevirisinde özgür davranarak yapıyı ve anlamı adeta yeniden kurmuş, kelime eklemeden çekinmemişlerdir.

Örnek 4."Zufällig fand er den Halteplatz und seine Umgebung von Menschen leer."34

"Tramvay durağında ve çevresinde, tesadüfen kimsecikler yoktu." ${ }^{35}$

"Tramvay durağında ve çevresinde tesadüfen kimse yoktu."(Yasemin Acar)

"Tesadüfen, durağı ve çevresini insanlardan arınmış bir şekilde buldu."(Ferhat Dönmez)

"Tesadüfen durak ve çevresinde kimsecikler yoktu.”(Zeynep Yıldız)

"Tesadüfen bir durak buldu ve çevresinde kimse yoktu.”(Derya Kara)

“Tesadüfen bir durak buldu ve onun çevresinde insanlar yoktu."(Sümeyra Tokmak)

“Tramvay durağı çevresinde tesadüfen kimsecikler yoktu."(Hatice Türk)

Necatigil, Acar, Yıldız ve Türk'ün bu cümleyi özgün metnin dışına çıkıp nesneleri yer zarfi yaparak uyarlama yoluyla çevirdiği ve anlam paralelliği kurulduğu görülüyor. Buldu fiili yoktu ile çevresini nesnesini çevresinde zarfiyla anlamlandırma, yabancı dil bilmeyen okur için fark edilmeyebilir. Hatta bu nitelemeler özgün metnin söylemini de etkilemez. Ancak burada izlenmesi gereken, "düşünceye aykırı bir ifadeyi farklı bir malzeme ile yineleme ve anlama değil, aksine farklı bir dilde ifade etmeyi başarmadır." 36 Dönmez nesneyi belirtmesi ve buldu fiiliyle özgün metne sadık kalırken, insanlardan arınmış olarak dolaylamasıyla, Kara ve Tokmak da aynı fiile yoktu olumsuzunu eklemeleriyle yapıyı bozuyorlar. Otobiyografik özelliklerle kurmacanın buluştuğu eserde üslûbun, "burjuva ailelerinde sanata yönelmeyi bir soysuzlaşma, bir çöküş, sanatkâr hayatı problematiğì" "'üzerine kurulması, kurulu düzeni ve burjuva yaşantısını ele verse de sanatçıyı alaya yakınlaştırır. Çünkü, "Tanrısal ve göze görünür tek şey güzelliktir... Sanatçının tinsel olana giden yoludur o!.. EROS yanımıza katılmadığı, önümüze düşmediği sürece, güzellik yolunda yürüyemeyiz!..."38 benzerliğinde manifesto sözler, klasik akılcılığa karşı bir başkaldırının, bir meydan okuyuşun sonucudur. "Eserdeki çizgisel (lineer) örüntü ile açık ve berrak betimlemeler, biçim ve biçem olarak klasik görüntüsü altında bütün özellikleriyle romantik" 39 izlerle doludur. Bu

\footnotetext{
34 Thomas, 2007, a.g.e. s. 10.

${ }^{35}$ Behçet, 2009, a.g.e. s. 12.

${ }^{36}$ Katerina, 1981, a.g.e. s. 80, 84.

${ }^{37}$ Gürsel Aytaç, Çağdaş Alman Edebiyatı, Kültür Bakanlığı Yayınları, Ankara, 1983, s. 237-238.

${ }^{38}$ Behçet, 2009, a.g.e. s. 234.

${ }^{39}$ Yücel, 30.01. 2013, a.g.e.
} 
çerçevede 18. yüzyılın sonlarına doğru Almanya'da gelişen ve bütün Avrupa'ya yayılan Romantizm (Coşumculuk), Sturm und Drang (Firtına ve Tepki) akımları ve Goethe'nin Leiden des jungen Werther's (Genç Werter'in Acıları) romanı, nasıl bir etki uyandırmışsa, Mann'ın Venedik'te Ölüm noveli de işlediği gerçeklikle aynı etkiyi uyandırmıştır. Werther salgını, mavi ceket, sarı pantolonla Avrupalı genç kuşakları nasıl sokaklara dökmüş, yasak aşk acıları, yalnızlık, hüzün ve tutkuyla aklını yitiren Werther'le özdeşleşme isteği onları nasıl intihara sürüklemişse, örtük kalmış dürtüler de Aschenbach'la ben'i öyle teslim almıştır. Genç Werther'le yüceltilen intihar kiliseyi nasıl kızdırmışsa, burjuva toplumunun değerlerine ters düşen duyguya yeniklik ve etik değerlerin yitimi Venedik'te Ölüm'le eleştirilmiştir. Biri diğerini çeken tematik unsurlar, toplumsal çarpıklığın seyrini trajik sonla bağlamıştır. İyice yaslandığı sandalyesinde uzaktakileri güç belâ izleyen Aschenbach, gördüğü saygıyı sonsuz bir vedâya bırakmıştır.

Örnek 5. "Ihm war aber, als ob der bleiche und liebliche Psychagog dort draussen ihm lächle, ihm winke; als ob er, die Hand aus der Hüfte lösend, hinausdeutete, voranschwebe ins Verheissungsvoll-Ungeheure." 40

“Aschenbach'a öyle geliyordu ki, ta ilerde o solgun yüzlü, sevimli, can alıcı çocuk kendisine gülümsemekte, el etmekte, elini belinden çözerek uzakları göstermekte, önünden vaatler dolu sonsuzluklara uçmaktadır." ${ }^{41}$

"Orada, ötelerde solgun yüzlü, sevimli ona gülümsüyor, el ediyormuş gibi; elini belinden çözerek öteleri gösteriyor, önünden ümit dolu vaatlerle muazzam bir şekilde gidiyormuş gibiydi."(Derya Kara)

“O Aschenbach'a solgun yüzlü, sevimli ve can alıcı geliyordu. Ona gülümsüyor, el sallıyor, elini belinden çekip uzaklara dalıyordu. Önünden sanki vaatlerle sonsuzluğa doğru uçuyordu."(Hatice Türk)

"Ona öyle geliyordu ki ileride o solgun yüzlü,can alıcı,gülmekte,el sallamakta,uzakları göstermekte,önünden sonsuzluğa doğru uçmaktadır.’(Sümeyra Tokmak)

"Sapsarı ve sevimli Psychagog orada ona gülümsüyor, el sallıyor, elini belinden çekip dişarıyı işaret ederek umut verici olağanüstülüklere süzülüyordu.”(Şerife Göçmen)

Mann'ın bu iki benzer cümlesi, sanki, -mış gibi anlamlarıla tanımlanan Konjuktiv II özelliği taşımaktadır. Necatigil, bu zaman yapısını öyle geliyordu ki ile kurarken bu defa iki cümleyi birleştiriyor. Özne sıfatlarıyla, zaman o ân'1 yansıttığı haliyle anlaşılmasını beklerken, Kara ve Türk'ün özneyi gizleyip serbest çeviri yaptığı, hatta Türk'ün iki cümleyi üçe çıkardığı görülüyor. Tokmak, Necatigil gibi als ob bağlacını geliyordu ki ile bir defa anlamlandırıp kelime tasarrufu yapıyor. Göçmen de cümleyi bire indirerek çeviriyor ve söylemin önemli unsuru Ungeheure kelimesini sözlük anlamıyla belirliyor. Ahlâkî yargı, statü koruma içgüdüsü, kaygısızlık ve çekicilik gibi sanata özgü görüşler Aschenbach'la Tadzio arasında birbirini izliyor. Dengeyi güzellik motifi bozmuş; yazarın o güne kadar biriktirdikleriyle platonik bağı karşı karşıya getiren ikilem, sonunu getirmiştir. Aschenbach, zihin ve beden savaşını kazansa da o güne kadar inandığı her şeyin güzellikle birlikte silinip gitmesine yenik düşmüştür. İnsanın yargılar arasında sevip yüceldiği, özleminse karşıdakini eksik tanımanın bir sonucu olarak kaldığı, belki de onun mirasıdır.

\footnotetext{
40 Thomas, 2007, a.g.e. s. 139.

${ }^{41}$ Behçet, 2009, a.g.e. s. 108.
} 


\section{SONUÇ}

Sanatçı zamanı, çevirmense onu ve anlattıklarını insana taşır. Sanatçı çağında yaşananları, toplumların sosyal, ekonomik, bireysel gelişmeleri ve çöküşlerini süzgecinden geçirerek eserine yansıtır. Onlardan devşirdiği her ürün ne bütünüyle kurgu, ne de gerçekliktir. Algıladıklarını sanatın gücüne vururken, gerçekliği kurmacaya buladıkça anlatının unsurları çözümü ve çeviriyi zorlaştırır. Tıpkı ikinci basamakta çevirmene teslim ettiği eseri gibi anlaşılmayı bekler. Bu açıdan Venedik'te Ölüm, ana karakterinin buhranlı haliyle ağırlaşsa da tasvirler ve devrik cümlelerle anlaşı1ır düzeydedir. Ancak amaç hata avcılığı olmasa da eserin durağan anlatısı çevirilerde de sezilmekte, etkin üslûbun neredeyse kaybolduğu görülmektedir. Hem ticari, hem de akademik kaygıyla yapılan çevirilerde kelimelerin kavram ve anlam alanları iyi irdelenmemiş; bölme ve eklemelerle cümle yapıları sapmıştır. Çeviri metotlarına bağlı kalma ve erek kültürün dizgesine uyma zorunluluğuna rağmen yapı kurulmuş olsa bile çoğu noktada anlam arkadan gelmektedir. Benzer aktarımlar, eserin sanat değerini düşürmektedir. Türk edebiyatına çok sayıda eser kazandıran yazar ve çevirmen Necatigil, çevirisinde en az yüksek lisans yapan öğrencileri kadar eserin özgün yapısıyla oynamış; öyküleme-ekleme-eksiltme yollarıyla okuru yazarın söylemine yakınlaştırmaya çalışmıştır. Sonuç itibariyle çeviriye soyunan hemen her kim olursa, iki dile de hakim olmanın yanı sıra yabancı kültür dizgesini iyi tanımalı, çeviribilime özgü metodoloji desteği almalıdır. Bu, yabancıyı anlamayı kolaylaştıracağı kadar dili de zenginleştirecektir. Çünkü sanatçı üslûbundaki usta tavır, yalan ve çılgınlık, itibar payesi komedya olsa da mutlak bir gerçeği fisıldar. Ki bu fisıltı yaşananların bir yansımasıdır ve öğeleri keyfince dümen çevirmeye izin vermez.

\section{KAYNAKÇA}

AKSOY, Nazan, Kurgulanmış Benlikler, İstanbul: İletişim Yayınları, 2009.

ARAK, Hüseyin, Thomas Mann‘1n Venedik’te Ölüm Başlıklı Eserinde Sanatçı İmajı; (Bkz. http//:egitim.erciyet.edu.tr)

AYTAÇ, Gürsel, Thomas Mann’ın Edebiyat Dünyası, Phoenix Yayınları, Ankara, 2010.

AYTAÇ, Gürsel, Genel Edebiyat Bilimi, İstanbul: Say Yayınları, 1. Baskı, 2003.

AYTAÇ, Gürsel, Çă̆daş Alman Edebiyatı, Kültür Bakanlığı Yayınları, Ankara, 1983.

BEHÇET, Necatigil, Venedik’te Ölüm, Can Yayınları, 4. Basım, 2009.

CARY, Edmond, Çeviri Nasıl Yapılmalı?, (Çev. Mete Çamdereli), İnsan Yayınları, İstanbul, 1996.

ÇÖLOĞLU, Erdem, Venedik’te Ölüm, Mann-Britten-Visconti Üzerinden Karşılaştırmalı Bir Analiz, (http://www.msgsumuzikoloji.com)

ERUZ, F. Sakine, Çeviribilim-Çeviriden Çeviribilime, Multilingual, İstanbul, 2003. http://www.benolmeden.com

İŞCEN, İsmail, Çevrim Kuramı, Seçkin Yayınevi, Ankara, 2002.

NURAL, Yücel, Venedik’te Ölüm ve Rousseau, 30.01.2013, (www.dipnotkitap.net)

OLIVER, Michael, E. Benjamin Britten, Phaidon, Londra-İngiltere, 1996.

ÖZER, Murat, Mantığın Bir Anlık Çöküşü, Radikal Kitap, 19.08.2011. 
REISS, Katerina, Möglichkeiten und Grenzen der Übersetzungskritik, Hueber Verlag, München, 1971.

SNELL-HORNBY, Mary, Übersetzungswissenschaft-EineNeuorientierung, UTB-Wissenschaft, Francke Verlag, Tübingen-Basel, 2. Auflage, 1994; (Bkz. Albrecht Neubert, Translationstudies and applied Linguistics, In: AILA Review I, 1984)

SCHROTER, Klaus, Thomas Mann, (Çev. Özden Saatçi-Karadana), Kavram Yayınları, İstanbul, 1999.

TEKIN, Mehmet, Roman Sanatı I (Romanın Unsurları), Ötüken Yayınları, İstanbul, 2001.

THOMAS, Mann, Der Tod in Venedig, Fischer Taschenbuch, 2007.

WANDRUSZKA, Mario, Die Mehrsprachigkeit des Menschen, München: Piper, 1979; (Bkz.

Werner Koller, Einführung in die Übersetzungswissenschaft, 4. Auflage, Quelle\&Meyer, Heidelber, 1992)

WILL, Wolfram, Interdiziplinerität: einneuesübersetzungswissenschaftliches Paradigma?, In: Paradigmenwechsel in der Translation: Festschrift für Albrect Neubert zu 70. Geburtstag/Hrsg. Von Peter A. Schmitt, Tübingen: Staufenburg, 2000.

WYSLING, Hans, Dichter über ihre Dichtungen, Buch 14/1, Heimeran/S. Fischer, 1975.

ZYBATOV, N. Lew, Sprache-Kultur-Translationoderwieso hat Translationetwas mit Sprachezu tun?, In: Translation zwischen Theorie und Praxis. Inssbrucker Ringvorlesungen zur Translationswissenschaft I. Forum Translationswissenschaft Bd. I. Lang Verlag: Frankfurt, 2002. 